\title{
Synthesis, Reactions, and Electrolyte Properties of Polymethacrylamides Having the L-threo- $\beta$-Hydroxyaspartic Acid Moiety
}

\author{
Fumio Sanda, Takashi Kurokawa, ${ }^{*}$ and Takeshi ENDO ${ }^{\dagger}$ \\ Research Laboratory of Resources Utilization, Tokyo Institute of Technology, \\ Nagatsuta-cho, Midori-ku, Yokohama 226-8503, Japan \\ * Applied Microbiology Research Center, Nippon Kayaku Co., \\ Koshikiya, Ageo, Saitama 362-0064, Japan \\ (Received October 28, 1998)
}

\begin{abstract}
The synthesis and radical polymerization of $N$-methacryloyl-L-threo- $\beta$-hydroxyaspartic acid dimethyl ester (MA-H-M) were carried out. The corresponding polymethacrylamide [poly(MA-H-M) with $M_{n} \mathrm{~s} 38900-484000$ was obtained in $28-93 \%$ yield. The ester moiety of poly(MA-H-M) could be hydrolyzed with alkaline in quantitative conversion to afford the corresponding polymer [poly(MA-H)], which could be also obtained by the radical polymerization of $N$ methacryloyl-L-threo- $\beta$-hydroxyaspartic acid (MA-H). Poly(MA-H) was quantitatively converted to poly(MA-H-M) by treatment with diazomethane. Poly $(\mathrm{MA}-\mathrm{H})$ showed $\mathrm{p} K_{\mathrm{a} 1}$ and $\mathrm{p} K_{\mathrm{a} 2}$ (3.74 and 6.37) larger than the model compound of the monomer unit of the polymer, $N$-pivaloyl-L-threo- $\beta$-hydroxyaspartic acid $\left(\mathrm{p} K_{\mathrm{a} 1} 2.75, \mathrm{p} K_{\mathrm{a} 2} 4.41\right)$. The viscosity of poly(MA-H) increased with $\mathrm{pH}$ up to $6-7$, the maximum value.

KEY WORDS Radical Polymerization / $N$-Methacryloyl-L-threo- $\beta$-hydroxyaspartic Acid Dimethyl Ester Electrolyte /
\end{abstract}

The synthesis and radical polymerization of various methacrylamides having $\alpha$-amino acid moieties have been reported, and much attention has been paid to their unique polymerization behavior, structures, and properties based on chirality. Morcellet et al. synthesized some polymethacrylamides with amino acids (alanine, glutamic acid, aspartic acid, asparagine, lysine) in the side chains, and studied complexing properties toward divalent metal ions. ${ }^{1}$ Sakota et al. studied photocopolymerization of $\mathrm{N}$-methacryloyl valine methyl ester with maleic anhydride, and suggested the induction of an asymmetric center into the polymer main chain. ${ }^{2}$ North et al. studied the copolymerization of methacrylamides containing the serine moiety with methyl methacrylate (MMA), and found nonlinear dependence of the specific rotation $v s$. incorporation of the chiral monomer. ${ }^{3}$ Recently, we reported the synthesis and radical polymerization of methacryl and acrylamides having amino acid and peptide moieties, and noted large polymerizability in spite of the bulky substituents, probably due to hydrogen bonding. ${ }^{4}$ In this work, we used $\beta$-hydroxyaspartic acid as the functional amino acid moiety in the methacrylamide derivatives. $\beta$-Hydroxyaspartic acid exists in human cerebrospinal fluid ${ }^{5}$ and urine. ${ }^{6} \beta$-Hydroxyaspartic acid was enzymatically synthesized from dihydroxyfumaric acid and L-glutamate, ${ }^{7}$ or by ammonolysis of cis- and trans-epoxysuccinic acid. ${ }^{8}$ L-threo- $\beta$-Hydroxyaspartic acid (L- $t$-HAA) was isolated as an antibiotic from a culture of $A$. Phaeospermum T-53. ${ }^{9}$ L- $t$-HAA is expected not only as an antibacterial material but also as a useful synthetic intermediate of drugs. Therefore, polymers based on L-t-HAA may serve as means for biological applications of L-t-HAA. This paper deals with synthesis and radical polymerization of a methacrylamide (MA-H-M) having L- $t$-HAA moiety, copolymerization of MA-H-M with MMA, hydrolysis of the polymer obtained, and examination of the elec-

To whom all correspondence should be addressed. trolyte properties.

\section{EXPERIMENTAL}

\section{Measurements}

${ }^{1} \mathrm{H}$ and ${ }^{13} \mathrm{C}$ NMR spectra were recorded on a Bruker $\mathrm{AC}-300$ plus spectrometer in $\mathrm{D}_{2} \mathrm{O}$, chloroform-d $\left(\mathrm{CDCl}_{3}\right)$, or dimethylsulfoxide- $d_{6}\left(\mathrm{DMSO}-d_{6}\right)$. FT-IR spectra were obtained with a Perkin Elmer model 1600FT-IR. Melting points (mp) were measured by a Yanaco micro melting point apparatus. Specific rotations $\left([\alpha]_{\mathrm{D}}\right)$ were measured on a JASCO DIP-370 digital polarimeter using a sodium lamp as a light source. High-resolution fast atomic bombardment-mass spectroscopic (HRFAB-MS) data were obtained with a JEOL JMS-AX505HA mass spectrometer. Number average molecular weights $\left(M_{n}\right)$ and polydispersity ratios $\left(M_{w} / M_{n}\right)$ were estimated by gel permeation chromatography (GPC) on a Tosoh HPLC HLC-8020 system, equipped with consecutive four polystyrene gel columns (TSK gels G6000H, G5000H, G4000H, and G2500H), using $N, N$-dimethylformamide (DMF, $5.8 \mathrm{mM}$ lithium bromide solution) as eluent at a flow rate of $1.0 \mathrm{~mL} \mathrm{~min}^{-1}$ by a polystyrene calibration, and refractive index (RI) and ultraviolet (UV) detectors. Thermal analysis was performed on Seiko Instruments TG/DTA220 and DSC220C. Glass transition temperatures $\left(T_{\mathrm{g}}\right)$ were taken as inflection points on a trace by differential scanning calorimetry (DSC) at a heating rate of $10^{\circ} \mathrm{C} \mathrm{min}^{-1}$. Temperatures $\left(T_{\mathrm{d} 10}\right)$ with $10 \%$ weight loss were determined by thermogravimetric analysis (TGA) at a heating rate of $10^{\circ} \mathrm{C} \mathrm{min}^{-1}$ under a nitrogen atmosphere.

\section{Materials}

L- $t$-HAA (Nippon Kayaku Co.), methacryloyl chloride (Tokyo Chemical Industry Co.), 2,2'-azobis(isobutyronitrile) (AIBN, Tokyo Chemical Industry Co.), and sodium persulfate (Aldrich Chemical Co.) were used as received. Polymerization solvents, methanol, DMF, and chloro- 
benzene were distilled before use.

\section{Synthesis of L-threo- $\beta$-Hydroxyaspartic Acid Dimethyl Ester Hydrochloride}

Thionyl chloride $(100 \mathrm{~mL}, 1.37 \mathrm{~mol})$ was added dropwise to methanol $(400 \mathrm{~mL}, 9.88 \mathrm{~mol})$ at $-10^{\circ} \mathrm{C}$. L- $t$-HAA $(30 \mathrm{~g}, 200 \mathrm{mmol})$ was added to the solution and the mixture was stirred at room temperature for 3 days, and concentrated by rotary evaporation. Ether was then added to the residue to precipitate white solid. The solid was filtered off and dried under reduced pressure. Yield $43 \mathrm{~g}(100 \%)$. ${ }^{1} \mathrm{H}$ NMR $\left(300 \mathrm{MHz}, \mathrm{D}_{2} \mathrm{O}\right) \delta 5.02(\mathrm{~s}, 1 \mathrm{H}$, $\left.\mathrm{CH}(\mathrm{OH}) \mathrm{CO}_{2} \mathrm{CH}_{3}\right), 4.68\left(\mathrm{~s}, 1 \mathrm{H}, \mathrm{CH}\left(\mathrm{NH}_{2} \cdot \mathrm{HCl}\right) \mathrm{CO}_{2}-\right.$ $\left.\mathrm{CH}_{3}\right), 3.90\left(\mathrm{~s}, 3 \mathrm{H}, \mathrm{CO}_{2} \mathrm{CH}_{3}\right), 3.86\left(\mathrm{~s}, 3 \mathrm{H}, \mathrm{CO}_{2} \mathrm{CH}_{3}\right) \mathrm{ppm}$.

\section{Synthesis of $M A-H-M$}

To a solution of 1-ethyl-3-(3-dimethylaminopropyl)carbodiimide hydrochloride $(\mathrm{EDC} \cdot \mathrm{HCl}, 92.3 \mathrm{~g}, 481$ $\mathrm{mmol})$ in dichloromethane $(500 \mathrm{~mL})$ was added methacrylic acid $(38 \mathrm{~g}, 441 \mathrm{mmol})$ at $0^{\circ} \mathrm{C}$, followed by the addition of triethylamine $(44.5 \mathrm{~g}, 441 \mathrm{mmol})$ and L-threo$\beta$-hydroxyaspartic acid dimethyl ester $(85.8 \mathrm{~g}, 402 \mathrm{mmol})$. The reaction mixture was stirred at room temperature overnight. The mixture was washed with ice-cold aqueous $\mathrm{NaCl}$ solution and the aqueous layer was extracted with dichloromethane $(300 \mathrm{~mL})$. The combined organic layer was washed with aqueous $\mathrm{HCl}(1 \mathrm{M})$, saturated aqueous $\mathrm{NaHCO}_{3}$, and water. The organic layer was separated and dried over anhydrous $\mathrm{MgSO}_{4}$, filtered, and concentrated by rotary evaporation. The residual syrup was purified by silica gel column chromatography eluted with $n$-hexane-ethyl acetate ( $4: 1$, volume ratio) to obtain $68 \mathrm{~g}$ of MA-H-M. Yield $69 \%,[\alpha]_{\mathrm{D}}^{20}+23.6^{\circ}(c 1.00, \mathrm{DMF})$, ${ }^{1} \mathrm{H}$ NMR $\left(300 \mathrm{MHz}, \mathrm{DMSO}-d_{6}\right) \delta 7.86(\mathrm{~d}, J=9.0 \mathrm{~Hz}$, $\mathrm{NH}), 5.95(\mathrm{~d}, J=9.0 \mathrm{~Hz}, \mathrm{OH}), 5.69\left(\mathrm{~s}, 1 \mathrm{H},=\mathrm{CH}_{2}\right), 5.42$ $\left(\mathrm{s}, 1 \mathrm{H},=\mathrm{CH}_{2}\right), 4.85-4.80\left(\mathrm{~m}, 1 \mathrm{H}, \mathrm{CH}(\mathrm{OH}) \mathrm{CO}_{2} \mathrm{CH}_{3}\right)$, $4.63-4.59\left(\mathrm{~m}, 1 \mathrm{H}, \mathrm{CH}(\mathrm{NH}) \mathrm{CO}_{2} \mathrm{CH}_{3}\right), 3.66(\mathrm{~s}, 3 \mathrm{H}$, $\left.\mathrm{CO}_{2} \mathrm{CH}_{3}\right), 3.60\left(\mathrm{~s}, 3 \mathrm{H}, \mathrm{CO}_{2} \mathrm{CH}_{3}\right), 1.84\left(\mathrm{~s}, 3 \mathrm{H}, \mathrm{CH}_{3}\right.$ (allyl)) ppm. ${ }^{13} \mathrm{C}$ NMR (75 MHz, DMSO-d 6$) \delta 172.4$, $169.7,168.4,139.2,120.7,70.9,54.6,53.4,53.1,18.5 \mathrm{ppm}$. IR (neat) 3378, 2957, 1747, 1666, 1624, 1518, 1438, 1351, 1274, 1209, 1104, 985, $937 \mathrm{~cm}^{-1}$. HRFAB-MS: $(\mathrm{M}+\mathrm{H})^{+}$ Calcd for $\mathrm{C}_{10} \mathrm{H}_{16} \mathrm{NO}_{6}$ : 246.0978. Found: 246.0970.

\section{Synthesis of $M A-H$}

To a solution of L- $t$-HAA $(7.45 \mathrm{~g}, 50 \mathrm{mmol})$ in aqueous $\mathrm{NaOH}(5 \mathrm{M}, 20 \mathrm{~mL})$ were added methacryloyl chloride $(90 \%, 5.7 \mathrm{~g}, 50 \mathrm{mmol})$ and aqueous $\mathrm{NaOH}(5 \mathrm{M}, 10 \mathrm{~mL})$ simultaneously at $0^{\circ} \mathrm{C}$. The mixture was stirred at $0^{\circ} \mathrm{C}$ for $3 \mathrm{~h}$, acidified by the addition of concentrated aqueous $\mathrm{HCl}$ and was washed twice with ether $(20 \mathrm{~mL})$, and extracted with ethyl acetate 15 times. The combined ethyl acetate layer was dried over anhydrous $\mathrm{MgSO}_{4}$, filtered, and the filtrate was concentrated by rotary evaporation to yield colorless oil. Yield $5.9 \mathrm{~g}(54 \%),[\alpha]_{\mathrm{D}}^{20}+20.2^{\circ}(c$ $\left.1.00, \mathrm{H}_{2} \mathrm{O}\right),{ }^{1} \mathrm{H}$ NMR $\left(300 \mathrm{MHz}, \mathrm{DMSO}-d_{6}\right) \delta 12.80$ (broad s, 2H, $\mathrm{CO}_{2} \mathrm{H}$ ), 7.58 (d, J=9.4 Hz, NH), 5.69 (s, $\left.1 \mathrm{H},=\mathrm{CH}_{2}\right), 5.43\left(\mathrm{~s}, 1 \mathrm{H},=\mathrm{CH}_{2}\right), 4.79(\mathrm{dd}, J=2.9$ and $\left.9.4 \mathrm{~Hz}, 1 \mathrm{H}, \mathrm{CH}(\mathrm{OH}) \mathrm{CO}_{2} \mathrm{H}\right), 4.53(\mathrm{~d}, J=2.9 \mathrm{~Hz}, 1 \mathrm{H}$, $\left.\mathrm{CH}(\mathrm{NH}) \mathrm{CO}_{2} \mathrm{H}\right), 3.35$ (br s, $\left.1 \mathrm{H}, \mathrm{OH}\right), 1.85\left(\mathrm{~s}, 3 \mathrm{H}, \mathrm{CH}_{3}\right.$ (allyl)) ppm. ${ }^{13} \mathrm{C}$ NMR (75 MHz, DMSO-d $)_{6} \delta 172.4$, $170.9,167.7,139.4,120.1,70.7,55.3,18.5$ ppm. IR (KBr) $3390,2987,1740,1655,1616,1528,1379,1210,1100$,
$939 \mathrm{~cm}^{-1}$. HRFAB-MS: $(\mathrm{M}+\mathrm{H})^{+}$Calcd for $\mathrm{C}_{8} \mathrm{H}_{12} \mathrm{NO}_{6}$ : 218.0665 Found: 218.0702.

\section{Synthesis of $N$-Pivaloyl-L-threo- $\beta$-hydroxyaspartic Acid Dimethyl Ester (Pivaloyl-HAA-M)}

To a solution of L-threo- $\beta$-hydroxyaspartic acid dimethyl ester hydrochloride $(8.5 \mathrm{~g}, 40 \mathrm{mmol})$ in DMF $(100 \mathrm{~mL})$ were added pivaloyl chloride $(5.8 \mathrm{~g}, 48 \mathrm{mmol})$ and triethylamine $(9.6 \mathrm{~g}, 96 \mathrm{mmol})$ simultaneously below $-20^{\circ} \mathrm{C}$. The mixture was stirred at $-20^{\circ} \mathrm{C}$ for $1 \mathrm{~h}$, poured into an ice-cold aqueous $\mathrm{NaCl}$ solution and extracted with ethyl acetate $(200 \mathrm{~mL})$ twice. The combined organic layer was washed with $\mathrm{NaHCO}_{3}$ aqueous solution and $\mathrm{NaCl}$ aqueous solution. The organic layer was dried over anhydrous $\mathrm{Na}_{2} \mathrm{SO}_{4}$. Evaporation to dryness in vacuo gave colorless crystals $(8.0 \mathrm{~g})$ of pivaloyl-HAA-M, followed by recrystallization from $n$-hexane-ethyl acetate. Yield $77 \%, \mathrm{mp} 103-104^{\circ} \mathrm{C},[\alpha]_{\mathrm{D}}^{20}+54.7^{\circ}(c 1.00$, $\left.\mathrm{CHCl}_{3} / \mathrm{MeOH}=3 / 1\right),{ }^{1} \mathrm{H}$ NMR $\left(300 \mathrm{MHz}\right.$, DMSO- $\left.d_{6}\right)$ $\delta 7.30(\mathrm{~d}, J=9.0 \mathrm{~Hz}, \mathrm{NH}), 5.94(\mathrm{~d}, J=9.0 \mathrm{~Hz}, \mathrm{OH})$, $4.82-4.78\left(\mathrm{~m}, 1 \mathrm{H}, \mathrm{CH}(\mathrm{OH}) \mathrm{CO}_{2} \mathrm{CH}_{3}\right), 4.57-4.61(\mathrm{~m}$, $\left.1 \mathrm{H}, \mathrm{CH}(\mathrm{NH}) \mathrm{CO}_{2} \mathrm{CH}_{3}\right), 3.65\left(\mathrm{~s}, 3 \mathrm{H}, \mathrm{CO}_{2} \mathrm{CH}_{3}\right), 3.59$ (s, $\left.3 \mathrm{H}, \mathrm{CO}_{2} \mathrm{CH}_{3}\right), 1.08\left(\mathrm{~s}, 9 \mathrm{H}, \mathrm{C}\left(\mathrm{CH}_{3}\right)_{3}\right) \mathrm{ppm}$.

\section{Synthesis of $N$-Pivaloyl-L-threo- $\beta$-hydroxyaspartic Acid (Pivaloyl-HAA) \\ To a solution of pivaloyl-HAA-M $(2.6 \mathrm{~g}, 10 \mathrm{mmol})$ in} $\mathrm{H}_{2} \mathrm{O}(24 \mathrm{~mL})$ was added a $1 \mathrm{M} \mathrm{NaOH}$ aqueous solution $(24 \mathrm{~mL})$ at $0-5^{\circ} \mathrm{C}$. The mixture was stirred at $0-5^{\circ} \mathrm{C}$ for $1.5 \mathrm{~h}$, treated with Dowex $50 \mathrm{~W}\left(\mathrm{H}^{+}\right)$and then freeze-dried to obtain a white powdery pivaloyl-HAA. Yield $2.3 \mathrm{~g}(98 \%),[\alpha]_{\mathrm{D}}^{20}+37.7^{\circ}\left(c 1.00, \mathrm{H}_{2} \mathrm{O}\right),{ }^{1} \mathrm{H}$ NMR $\left(300 \mathrm{MHz}, \mathrm{D}_{2} \mathrm{O}\right) \delta 5.05\left(\mathrm{~s}, 1 \mathrm{H}, \mathrm{CH}(\mathrm{OH}) \mathrm{CO}_{2} \mathrm{H}\right)$, $4.86\left(\mathrm{~s}, 1 \mathrm{H}, \mathrm{CH}(\mathrm{NH}) \mathrm{CO}_{2} \mathrm{CH}_{3}\right), 1.14\left(\mathrm{~s}, 9 \mathrm{H}, \mathrm{C}\left(\mathrm{CH}_{3}\right)_{3}\right)$ ppm.

\section{Radical Polymerization of $M A-H-M$}

To MA-H-M $(735 \mathrm{mg}, 3 \mathrm{mmol})$ in a polymerization tube was introduced AIBN $(0.03 \mathrm{mmol})$, and then a solvent $(3 \mathrm{~mL})$. The tube was cooled, degassed, sealed off, and heated at $60^{\circ} \mathrm{C}$ for $20 \mathrm{~h}$. The mixture was poured into ether $(100 \mathrm{~mL})$ to precipitate a white powdery polymer. The polymer was collected and dried in vacuo at $50^{\circ} \mathrm{C}$.

\section{Radical Polymerization of $M A-H$}

A solution of MA-H $(2.17 \mathrm{~g}, 10 \mathrm{mmol})$, sodium persulfate ( $24 \mathrm{mg}, 0.1 \mathrm{mmol}$ ), aqueous $\mathrm{NaOH}(5 \mathrm{M}$, $9.5 \mathrm{~mL})$, and water $(0.5 \mathrm{~mL})$ was heated at $60^{\circ} \mathrm{C}$ under nitrogen for $20 \mathrm{~h}$. The polymerization mixture was treated with Dowex 50W $\left(\mathrm{H}^{+}\right)$and Dowex WGR $\left(\mathrm{OH}^{-}\right)$, and then freeze-dried. The white powder obtained was washed with ethyl acetate and dried in vacuo at $50^{\circ} \mathrm{C}$ to afford poly(MA-H). Yield $1.76 \mathrm{~g}(80 \%)$

\section{Methyl Esterification of Poly $(M A-H)$}

To a solution of poly(MA-H) $(217 \mathrm{mg})$ in methanol $(7 \mathrm{~mL})$ containing $3 \mathrm{vol} \%$ water was added a solution of diazomethane in $n$-hexane-chloroform at room temperature. The mixture was stirred for $30 \mathrm{~min}$ and poured into ether $(200 \mathrm{~mL})$ to precipitate a polymer [poly(MA-HM)]. Yield $220 \mathrm{mg}(90 \%)$. 


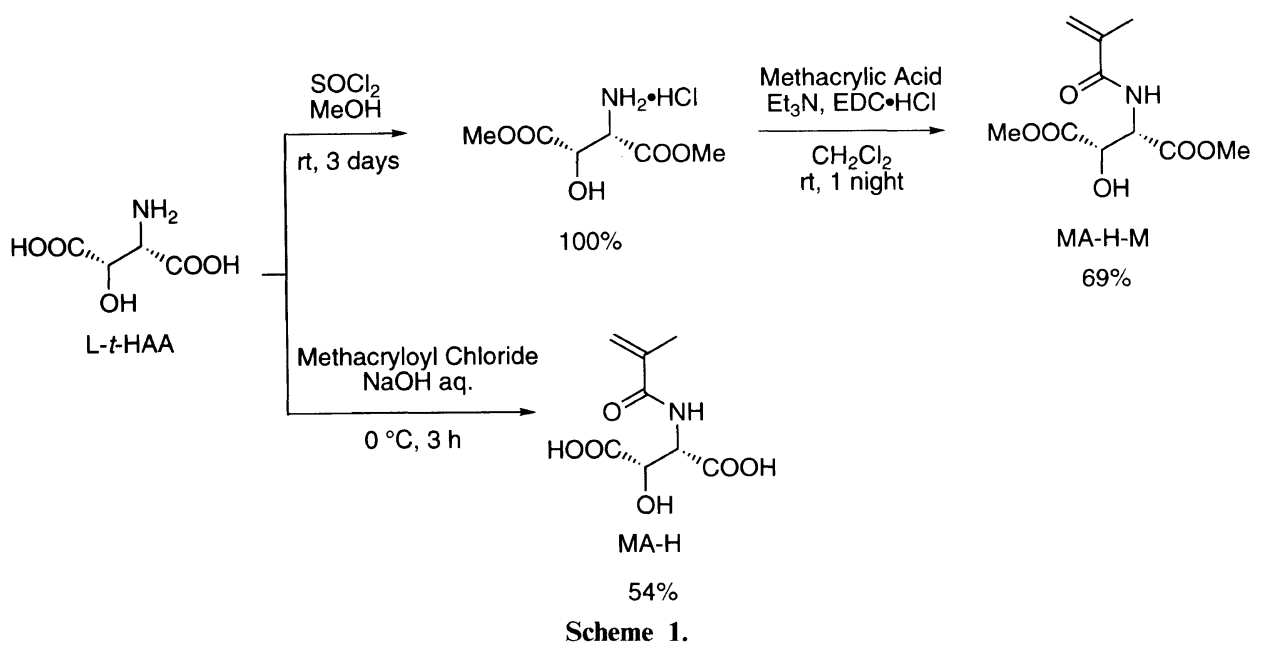

Table I. Radical polymerization of MA-H-M and MA-H

\begin{tabular}{|c|c|c|c|c|c|c|c|c|c|}
\hline \multirow{2}{*}{ Run monomer } & \multirow{2}{*}{ Init. } & \multirow{2}{*}{ Solv. } & \multirow{2}{*}{$\frac{\text { Conv. }^{a}}{\%}$} & \multirow{2}{*}{$\frac{\text { Yield }^{\mathrm{b}}}{\%}$} & \multirow{2}{*}{$M_{n}{ }^{\mathrm{c}}$} & \multirow{2}{*}{$M_{w} / M_{n}{ }^{\mathrm{c}}$} & \multirow{2}{*}{$\frac{[\alpha]_{\mathrm{D}}^{20 \mathrm{~d}}}{0}$} & \multirow{2}{*}{$\frac{T_{\mathrm{g}}^{\mathrm{e}}}{{ }^{\circ} \mathrm{C}}$} & \multirow{2}{*}{$\frac{T_{\mathrm{d} 10}{ }^{\mathrm{f}}}{{ }^{\circ} \mathrm{C}}$} \\
\hline & & & & & & & & & \\
\hline 1 MA-H-M & AIBN & None & 27 & 28 & 484000 & 7.31 & $\ldots \mathrm{g}$ & 124 & 271 \\
\hline 2 MA-H-M & AIBN & $\mathrm{MeOH}$ & 80 & 80 & 42000 & 1.99 & +20.1 & 108 & 271 \\
\hline 3 MA-H-M & AIBN & DMF & 88 & 84 & 38900 & 2.37 & +22.8 & 121 & 272 \\
\hline 4 MA-H-M & AIBN & $\mathrm{PhCl}$ & 97 & 93 & 71300 & 3.06 & +20.7 & 122 & 271 \\
\hline 5 MA-H & $\mathrm{Na}_{2} \mathrm{~S}_{2} \mathrm{O}_{8}$ & $\mathrm{H}_{2} \mathrm{O}$ & $\ldots g$ & $80^{\mathrm{i}}$ & $47700^{j}$ & $2.73^{j}$ & $+33.3^{\mathrm{k}}$ & $\_\mathrm{g}$ & $\ldots g$ \\
\hline $6 \mathrm{MA}-\mathrm{H}$ & $\mathrm{Na}_{2} \mathrm{~S}_{2} \mathrm{O}_{8}$ & aq $\mathrm{NaOH}^{\mathrm{h}}$ & -8 & $77^{\mathrm{i}}$ & $43200^{j}$ & $2.29^{j}$ & $+32.5^{\mathrm{k}}$ & 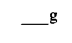 & $\ldots g$ \\
\hline
\end{tabular}

Conditions: monomer $3 \mathrm{mmol}$, solvent $3 \mathrm{~mL}$ for MA-H-M, monomer $10 \mathrm{mmol}$, solvent $10 \mathrm{~mL}$ for $\mathrm{MA}-\mathrm{H}$, initiator $1 \mathrm{~mol} \%, 60^{\circ} \mathrm{C}, 20 \mathrm{~h}$, ${ }^{a}$ Determined by ${ }^{1} \mathrm{H}$ NMR. ${ }^{\mathrm{b}}$ Ether-insoluble part. ${ }^{\mathrm{c}}$ Estimated by GPC based on polystyrene standards, eluent; LiBr solution in DMF $(5.8 \mathrm{mM}) .{ }^{\mathrm{d}}$ Measured by a polarimeter at $20^{\circ} \mathrm{C}\left(\mathrm{c} 1.00\right.$, DMF $: \mathrm{H}_{2} \mathrm{O}=1: 1$, volume ratio). ${ }^{\mathrm{e}}$ Determined by DSC. ${ }^{\mathrm{f}}$ Determined by TGA under nitrogen. ${ }^{\mathrm{g}}$ Not determined. ${ }^{\mathrm{h}} 5 \mathrm{M}$. 'Y Yield after successive treatment with acidic and alkaline ion exchange resins, followed by washing with ethyl acetate. ${ }^{j}$ Estimated after transformation into the corresponding poly(MA-H-M) by methyl esterification with diazomethane. ${ }^{\mathrm{k}}$ Measured by a polarimeter at $20^{\circ} \mathrm{C}\left(c 1.00, \mathrm{H}_{2} \mathrm{O}\right)$.

\section{Alkaline Hydrolysis of Poly $(M A-H-M)$}

To a solution of poly(MA-H-M) $(735 \mathrm{mg}, 3 \mathrm{mmol}$ per unit, $\left.M_{n} 41500, M_{w} / M_{n} 2.49\right)$ was added aqueous $\mathrm{NaOH}(1 \mathrm{M}, 30 \mathrm{~mL})$. The mixture was stirred at room temperature for $40 \mathrm{~min}$, treated with Dowex 50W $\left(\mathrm{H}^{+}\right)$ and freeze-dried to obtain a white powdery polymer. Yield $620 \mathrm{mg}(95 \%),[\alpha]_{\mathrm{D}}^{20}+31.2^{\circ}\left(c 1.00, \mathrm{H}_{2} \mathrm{O}\right)$.

\section{Acid Hydrolysis of Poly $(M A-H)$}

A mixture of poly(MA-H) $\left(1.4 \mathrm{~g}, M_{n} 52000, M_{w} / M_{n}\right.$ 2.22) and aqueous $\mathrm{HCl}(6 \mathrm{M}, 100 \mathrm{~mL})$ was stirred at $105^{\circ} \mathrm{C}$ for $72 \mathrm{~h}$. After cooling, the precipitated mass was collected, and treated with a solution of diazomethane in methanol-chloroform-ether. A methyl esterificated polymer was isolated by precipitation with ether. Yield

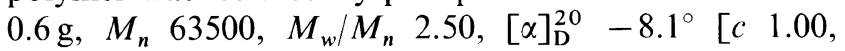
$\mathrm{CHCl}_{3} / \mathrm{MeOH}=3 / 1$ (volume ratio)].

\section{RESULTS AND DISCUSSION}

\section{Synthesis of Monomers}

Scheme 1 illustrates the synthetic procedure of the monomers, MA-H-M and MA-H. MA-H-M was synthesized by the esterification of L- $t$-HAA, followed by condensation with methacrylic acid using $\mathrm{EDC} \cdot \mathrm{HCl}$ as the condensation reagent. Methacrylation selectively took place at the amino group to afford the corresponding methacrylamide at room temperature. ${ }^{10}$ Methacryla- tion of the hydroxyl group was suppressed so as not to afford the methacrylate. MA-H was synthesized by the reaction of L-t-HAA with methacryloyl chloride. The structures of the monomers were confirmed by NMR and FAB mass spectroscopy.

\section{Radical Polymerization of $M A-H-M$ and $M A-H$}

Radical polymerization of MA-H-M was carried out with AIBN as the initiator at $60^{\circ} \mathrm{C}$ in bulk, $\mathrm{MeOH}, \mathrm{DMF}$, and $\mathrm{PhCl}$. For $\mathrm{MA}-\mathrm{H}$, this was done with $\mathrm{Na}_{2} \mathrm{~S}_{2} \mathrm{O}_{8}$ in $\mathrm{H}_{2} \mathrm{O}$ and aqueous $\mathrm{NaOH}$. Table I summarizes the conditions and results of the polymerization. The polymerization proceeded homogeneously except for MA-H-M in PhCl: the polymerization mixture separated into two phases. The molecular weight of the polymer obtained in the bulk polymerization was much larger compared with solution polymerizations, while conversion and yield were low. This might be responsible for the solidification of the polymerization mixture $(1.5 \mathrm{~h}$ after polymerization was initiated). The structures of the obtained polymers were confirmed as the corresponding polymethacrylamides, poly(MA-H-M) and poly(MA-H) by NMR and IR spectroscopy. Figures 1 and 2 show the ${ }^{1} \mathrm{H}$ NMR spectra of the polymers along with assignments of the signals. The molecular weight of poly(MA-H) was estimated after esterification into the corresponding poly(MA-H-M) with diazomethane, because poly(MA-H) was not soluble in DMF, the GPC 


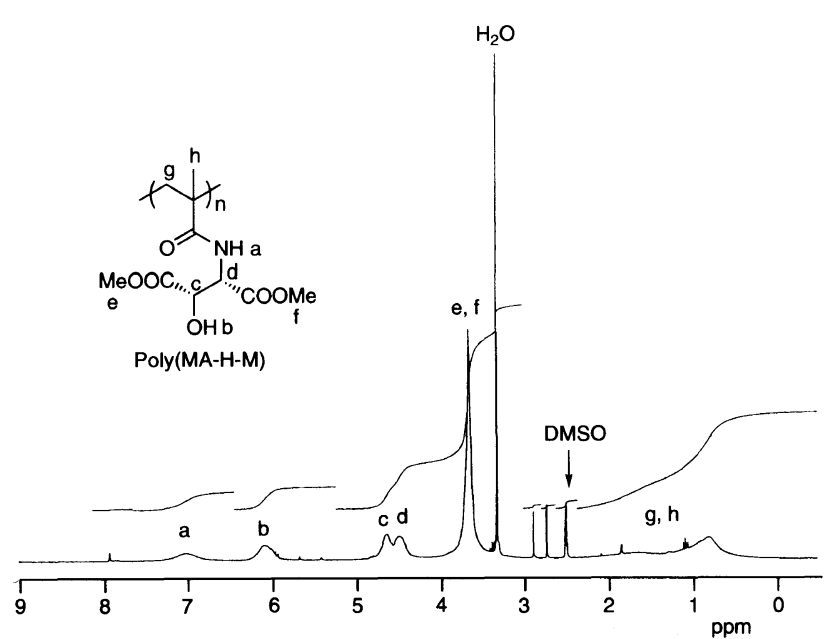

Figure 1. ${ }^{1} \mathrm{H}$ NMR spectrum of poly(MA-H-M) obtained for the polymerization of MA-H-M in DMF initiated with AIBN at $60^{\circ} \mathrm{C}$ : $[\mathrm{MA}-\mathrm{H}-\mathrm{M}]=1 \mathrm{M} ;[\mathrm{AIBN}]=0.01 \mathrm{M}$ (run 3 in Table $\mathrm{I}$ ).

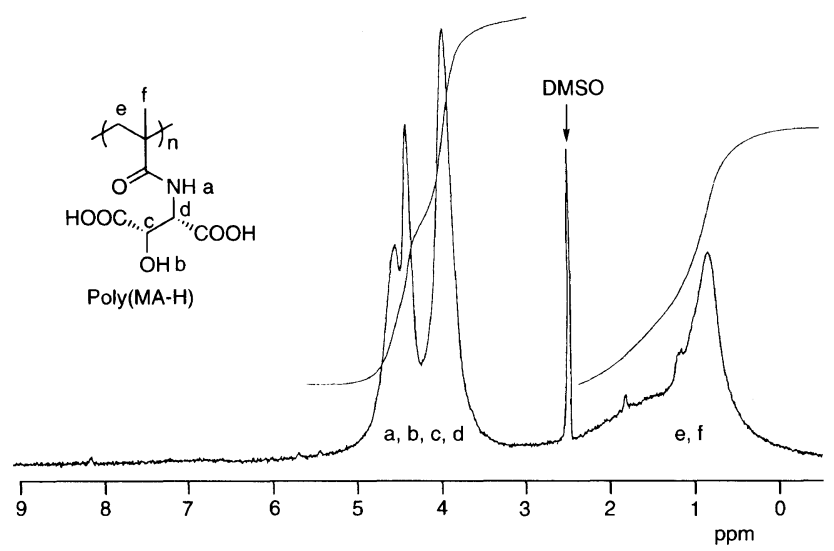

Figure 2. ${ }^{1} \mathrm{H}$ NMR spectrum of poly(MA-H) obtained for the polymerization of MA-H in $\mathrm{H}_{2} \mathrm{O}$ initiated with $\mathrm{Na}_{2} \mathrm{~S}_{2} \mathrm{O}_{8}$ at $60^{\circ} \mathrm{C}$ : $[\mathrm{MA}-\mathrm{H}]=1 \mathrm{M} ;\left[\mathrm{Na}_{2} \mathrm{~S}_{2} \mathrm{O}_{8}\right]=0.01 \mathrm{M}$ (run 5 in Table I).

solvent. $[\alpha]_{\mathrm{D}}^{20}, T_{\mathrm{g}}$, and $T_{\mathrm{d} 10}$ were little influenced by the solvent used in the polymerization.

\section{Alkaline Hydrolysis of Poly $(M A-H-M)$}

Alkaline hydrolysis of the methyl ester group of poly(MA-H-M) was performed in a $1-\mathrm{M}$ aqueous $\mathrm{NaOH}$ solution at room temperature to obtain poly(MA-H) quantitatively. The ${ }^{1} \mathrm{H}$ NMR spectral pattern of this poly(MA-H) obtained by the hydrolysis was completely similar to that of poly(MA-H) obtained in the radical polymerization of MA-H. The hydroxyl group of poly(MA-H-M) should contribute to the hydrophilicity of poly(MA-H-M), with consequent quantitative hydrolysis. The amide group was not hydrolyzed under this condition, because the hydrolyzed polymer showed negative results in a ninhydrin test. $[\alpha]_{\mathrm{D}}^{20}$ and $T_{\mathrm{d} 10}$ of poly (MA-H) obtained by the hydrolysis of poly(MA-HM) were $+31.2^{\circ}\left(c 1.0, \mathrm{H}_{2} \mathrm{O}\right)$ and $202^{\circ} \mathrm{C}$, respectively, and nearly equal to those of poly $(\mathrm{MA}-\mathrm{H})$ obtained by the radical polymerization of $\mathrm{MA}-\mathrm{H}\left(+32.5-+33.3^{\circ}\right.$, runs 5 and 6 in Table I).

\section{Acid Hydrolysis of Poly $(M A-H)$}

The amide group of poly(MA-H) was subjected to hydrolysis in $6 \mathrm{M}$ aqueous $\mathrm{HCl}$ at $105^{\circ} \mathrm{C}$ for $15 \mathrm{~h}$ to afford
Table II. Specific rotations of polymers

\begin{tabular}{|c|c|c|c|}
\hline \multirow[b]{2}{*}{ Run } & \multirow[b]{2}{*}{ Compound } & \multicolumn{2}{|c|}{$[\alpha]_{\mathrm{D}}^{20} / 0$} \\
\hline & & $\begin{array}{c}\text { in } \\
\text { DMF } \mathrm{H}_{2} \mathrm{O}= \\
1: 1^{\mathrm{a}}\end{array}$ & $\begin{array}{c}\text { in } \\
\mathrm{CHCl}_{3}-\mathrm{MeOH}= \\
3: 1^{\mathrm{a}}\end{array}$ \\
\hline 1 & Poly(MA-H-M) & +22.8 & +41.5 \\
\hline 2 & Poly $(\text { MA-H })^{\mathrm{b}}$ & +21.1 & - \\
\hline 3 & $\operatorname{Poly}\left(\mathrm{MA}-\mathrm{H}_{9}-\mathrm{co}-\mathrm{MA}_{91}\right)^{\mathrm{c}}$ & -8.6 & - \\
\hline 4 & Poly(MA-H-M $\left.{ }_{9}-c o-\mathrm{MMA}_{91}\right)^{\mathrm{d}}$ & - & -8.1 \\
\hline 5 & Poly(MA-H-M $\left.{ }_{9}-c o-\mathrm{MMA}_{91}\right)^{\mathrm{c}}$ & - & +6.3 \\
\hline 6 & Pivaloyl-HAA-M & - & +54.7 \\
\hline
\end{tabular}

a partially hydrolyzed polymer along with L- $t$-HAA hydrochloride in $40 \%$ yield, whose structure was confirmed by electrophoresis. No epimerization of the HAA moiety took place during alkaline and acid hydrolyses. ${ }^{11}$ After acid hydrolysis of poly(MA-H) for $72 \mathrm{~h}$ under similar conditions, the polymer was treated with diazomethane to obtain the corresponding methyl-esterificated polymer, whose residual HAA unit was $9 \%$.

Table II summarizes the specific rotations of the polymers examined in this work, along with pivaloylHAA-M, a model compound of the monomer unit of poly(MA-H-M). Poly(MA-H-M) (run 1), poly(MA-H) (run 2) obtained by alkaline hydrolysis of poly(MA-H-M) (run 1), and pivaloyl-HAA-M (run 6) showed positive specific rotation, while poly(MA- $\mathrm{H}_{9}-\mathrm{co}-\mathrm{MA}_{91}$ ) (run 3) obtained by the acid hydrolysis of poly(MA-H-M) (run 1), and poly(MA-H-M $\mathrm{M}_{9}-\mathrm{co}-\mathrm{MMA}_{91}$ ) (run 4) obtained by the treatment by diazomethane of this poly $\left(\mathrm{MA}-\mathrm{H}_{9}-\mathrm{co}-\right.$ $\mathrm{MA}_{91}$ ) (run 3) showed negative specific rotation. Interestingly, poly(MA-H-M $\mathrm{M}_{9}-\mathrm{co}-\mathrm{MMA}_{91}$ ) (run 5) obtained by the copolymerization with MA-H-M with MMA showed a positive value. Asymmetric induction to the polymer main chain, unit sequence, and/or tacticity may be the reason for this, although there is no concrete evidence.

\section{Radical Copolymerization of $M A-H-M$ with Methyl Methacrylate}

Radical copolymerization of MA-H-M with MMA was examined at $60^{\circ} \mathrm{C}$ in DMF in the presence of AIBN, where total monomer concentration was fixed at $1 \mathrm{M}$. They copolymerized satisfactorily to afford the corresponding copolymers with $M_{n}$ s $c a$. 53000-65000 and $T_{\mathrm{g}} \mathrm{s} 120-125^{\circ} \mathrm{C}$ in good yield independent of the monomer feed ratio as shown in Table III. Copolymer composition was determined by comparing the ${ }^{1} \mathrm{H}$ NMR integration ratios of the ester methyl protons of MA-H-M and MMA units around 3.8 and $3.6 \mathrm{ppm}$, respectively. The specific rotation of the copolymer decreased and the decomposition temperature increased with decrease in the incorporation ratio of the MA-H-M unit.

\section{Electrolyte Properties}

Aqueous solution of poly(MA-H) was titrated with aqueous $\mathrm{NaOH}$. Figure 3 illustrates the titration curve of poly(MA-H) along with that of pivaloyl-HAA, the 
Synthesis of Polymethacrylamide

Table III. Radical copolymerization of MA-H-M with methyl methacrylate

\begin{tabular}{|c|c|c|c|c|c|c|c|c|}
\hline \multirow{2}{*}{ Run } & \multirow{2}{*}{$\begin{array}{c}\begin{array}{c}\text { MA-H-M/MMA } \\
\text { in feed }\end{array} \\
\text { mol } \%\end{array}$} & \multirow{2}{*}{$\frac{\text { Yield }^{\mathrm{a}}}{\%}$} & \multirow{2}{*}{$\frac{\begin{array}{c}\text { MA-H-M/MMA } \\
\text { in copolymer }\end{array}}{\mathrm{mol} \%}$} & \multirow{2}{*}{$M_{n}^{\mathrm{c}}$} & \multirow{2}{*}{$M_{w} / M_{n}^{\mathrm{c}}$} & \multirow{2}{*}{$\frac{[\alpha]_{D}^{20 d}}{0}$} & \multirow{2}{*}{$\frac{T_{\mathrm{g}}^{\mathrm{e}}}{{ }^{\mathrm{c}} \mathrm{C}}$} & \multirow{2}{*}{$\frac{T_{\mathrm{d} 10}{ }^{\mathrm{f}}}{{ }^{\mathrm{C}}}$} \\
\hline & & & & & & & & \\
\hline 1 & $100 / 0$ & 84 & $100 / 0$ & 58800 & 2.22 & +41.5 & 121 & 271 \\
\hline 2 & $50 / 50$ & 77 & $41 / 59$ & 65400 & 1.89 & +23.8 & 125 & 289 \\
\hline 3 & $25 / 75$ & 81 & $19 / 81$ & 53900 & 1.74 & +11.4 & 122 & 294 \\
\hline 4 & $13 / 87$ & 73 & 9/91 & 53400 & 1.70 & +6.3 & $\ldots g$ & $\ldots g$ \\
\hline
\end{tabular}

Conditions: total monomer $3 \mathrm{mmol}$, DMF $3 \mathrm{~mL}$, AIBN $1 \mathrm{~mol} \%, 60^{\circ} \mathrm{C}, 20 \mathrm{~h}$. ${ }^{a}$ Ether-insoluble part. ${ }^{\mathrm{b}}$ Determined by ${ }^{1} \mathrm{H}$ NMR. ${ }^{\mathrm{c}}$ Estimated by GPC based on polystyrene standards, eluent; $\mathrm{LiBr}$ solution in DMF $(5.8 \mathrm{mM}) .{ }^{\mathrm{d}}$ Measured by a polarimeter at $20^{\circ} \mathrm{C}\left(\mathrm{c} 1.00, \mathrm{CHCl}_{3}: \mathrm{CH}_{3} \mathrm{OH}=3: 1\right.$, volume ratio). ${ }^{\mathrm{e}}$ Determined by DSC. ${ }^{\mathrm{f}}$ Determined by TGA under nitrogen. ${ }^{\mathrm{g}}$ Not determined.

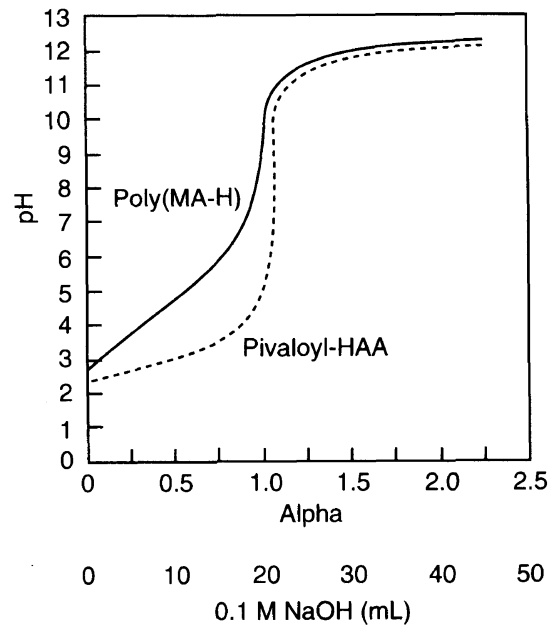

Figure 3. Titration curves of poly(MA-H) and pivaloyl-HAA in water with $0.1 \mathrm{M}$ aqueous $\mathrm{NaOH}$. Alpha represents the neutralization coefficient. Poly(MA-H): $20 \mathrm{mM} \times 50 \mathrm{~mL}, M_{n}=34800, M_{w} / M_{n}=2.46$, pivaloyl-HAA: $20 \mathrm{mM} \times 50 \mathrm{~mL}$.

model compound of the monomer unit of the polymer. Poly(MA-H) showed $\mathrm{p} K_{\mathrm{a} 1}$ and $\mathrm{p} K_{\mathrm{a} 2}$ (3.74 and 6.37) larger than the model compound of the monomer unit of the polymer, $N$-pivaloyl-L-threo- $\beta$-hydroxyaspartic acid $\left(\mathrm{p} K_{\mathrm{a} 1} 2.75, \mathrm{p} K_{\mathrm{a} 2}\right.$ 4.41). Differences between poly(MA-H) and pivaloyl-HAA might be caused by the "polymer effect," e.g., the effective proton concentration of poly(MA-H) might be low, because electrostatic interactions between the neighboring ionizable groups strongly influence $\mathrm{p} K_{\mathrm{a}} \cdot{ }^{12}$

\section{Viscosity and $p H$}

Figure 4 depicts the viscosity of poly (MA-H) vs. $\mathrm{pH}$, along with the data of poly(methacrylic acid) and poly(acrylic acid) for comparison. The viscosity of poly(MA-H) increased with $\mathrm{pH}$ up to $\mathrm{pH} 6-7$, the maximum value $\left(0.677 \mathrm{dL} \mathrm{g}^{-1}\right)$, while the viscosities of poly(methacrylic acid) and poly(acrylic acid) reached 1.02 and 1.07, respectively. The carboxylate anions of poly(methacrylic acid) and poly(acrylic acid) may be more affected by anionic-anionic repulsion compared with poly(MA-H), because the carboxylate groups of the formers are closer to the polymer main chains than those of the latter. Consequently, poly(methacrylic acid) and poly(acrylic acid) spread more than poly(MA-H) in solution, with consequently higher viscosity.

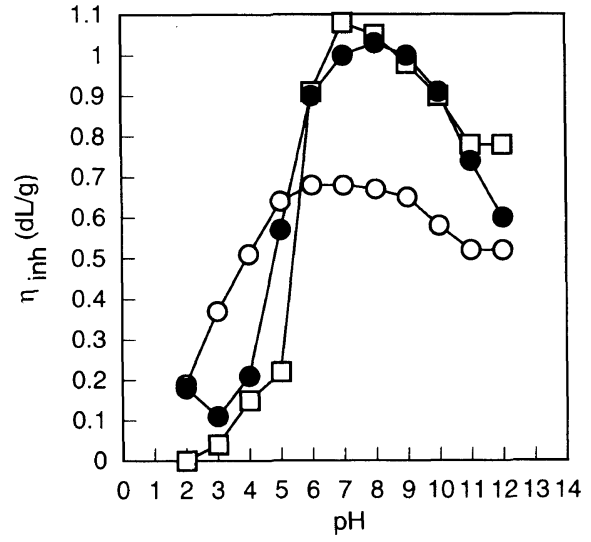

Figure 4. Relationships between viscosities of poly(MA-H) $(O)$, poly(methacrylic acid) $(\square)$, and poly(acrylic acid) (O) vs. pH. $[$ poly $($ MA-H $)]=[$ poly $($ methacrylic acid $)]=[$ poly $($ acrylic acid $)]=5$ $\mathrm{mM}$ (per monomer unit in aqueous $\mathrm{NaClO}_{4}$ ). Poly(MA-H): $M_{n}=34800, M_{w} / M_{n}=2.46$, poly (methacrylic acid): $M_{n}=39200$, $M_{w} / M_{n}=1.90 ;$ poly (acrylic acid): $M_{n}=18600, M_{w} / M_{n}=1.94$.

\section{Antibacterial Activity}

The antibacterial activity of MA-H-M, MA-H, poly(MA-H-M), and poly(MA-H) was evaluated against Escherichia coli K-12, Pseudomonas aeruginosa IFO3510, Xantomonas oryzae IFO-3445, Bacillus subtilis PCI219, Staphylococcus aureus FAD209P, and Mycobacterium smegmatis ATCC607 by the paper disk method, but no apparent antibacterial activity could be detected so far. Further investigation on antibacterial activity is now under way.

\section{REFERENCES AND NOTES}

1. (a) J. Morcellet-Sauvage, M. Morcellet, and C. Loucheux, Makromol. Chem., 182, 949 (1981). (b) M. Morcellet, C. Loucheux, and H. Daoust, Macromolecules, 15, 890 (1982). (c) J. Morcellet-Sauvage, M. Morcellet, and C. Loucheux, Makromol. Chem., 183, 821 (1982). (d) J. Morcellet-Sauvage, M. Morcellet, and C. Loucheux, Makromol. Chem., 183, 831 (1982). (e) J. Morcellet-Sauvage, M. Morcellet, and C. Loucheux, Polym. Bull., 10, 473 (1983). (f) A. Lekchiri, J. Morcellet, and M. Morcellet, Macromolecules, 20, 49 (1987). (g) C. Methenitis, J. Morcellet, and M. Morcellet, Eur. Polym. J., 23, 287 (1987). (h) C. Methenitis, J. Morcellet, G. Pneumatikakis, and M. Morcellet, Macromolecules, 27, 1455 (1994).

2. (a) K. Nishihara, A. Suzuoka, and N. Sakota, J. Polym. Sci., Polym. Chem. Ed., 11, 2315 (1973). (b) K. Nishihara and N. Sakota, J. Polym. Sci., Polym. Chem. Ed., 11, 3171 (1973).

3. S. M. Bush and M. North, Polymer, 37, 4649 (1996).

4. (a) F. Sanda, M. Nakamura, T. Endo, T. Takata, and H. Handa, Macromolecules, 27, 7928 (1994). (b) H. Murata, F. Sanda, and T. Endo, Macromolecules, 29, 5535 (1996). (c) F. Sanda, M. 
Nakamura, and T. Endo, Macromolecules, 29, 8064 (1996). (d) F. Sanda, M. Nakamura, and T. Endo, Chem. Lett., 175 (1997). (e) F. Sanda, T. Abe, and T. Endo, J. Polym. Sci., Part A, Polym. Chem., 35, 2619 (1997). (f) H. Murata, F. Sanda, and T. Endo, Macromolecules, 30, 2902 (1997). (g) H. Murata, F. Sanda, and T. Endo, J. Polym. Sci., Part A, Polym. Chem., 36, 1679 (1998).

(h) F. Sanda, F. Ogawa, and T. Endo, Polymer, 39, 5543 (1998).

(i) F. Sanda, M. Nakamura, and T. Endo, J. Polym. Sci., Part A, Polym. Chem., 36, 2823 (1998).

5. T. L. Perry and R. T. Jones, J. Clin. Invest., 40, 1363 (1961)

6. F. Tominaga, C. Hiwaki, T. Maekawa, and H. Yoshida, J. Biochem., 53, 227 (1963).

7. H. J. Sallach and T. H. Peterson, J. Biol. Chem., 223, 629 (1956).

8. H. Okai, N. Imamura, and N. Izumiya, Bull. Chem. Soc. Jpn.,
40, 2154 (1967).

9. T. Ishiyama, T. Furuta, M. Takai, and Y. Okimoto, J. Antibiot., 28, 821 (1975).

10. The crude MA-H-M was obtained quantitatively, whose NMR and IR spectra showed almost the similar patterns with those after purification, where MA-H-M was obtained in $69 \%$ yield.

11. On high voltage cellulose-thin layer electrophoresis $\left(850 \mathrm{~V}, 4^{\circ} \mathrm{C}\right.$, $4 \mathrm{~min})$ using a buffer of formic acid-acetic acid-water $(25: 75: 900$, volume ratio), the relative mobility $(0.44)$ of the resulting HAA to L-alanine was the same as that of the threo isomer $(0.44)$ but different from that of the erythro isomer (0.59), which were checked with ninhydrin.

12. R. Barbucci, M. Casolaro, M. Nocentini, S. Corezzi, P. Ferruti, and V. Barone, Macromolecules, 19, 37 (1986). 